\title{
SAMORZĄDNA RZECZPOSPOLITA - 25 LAT SAMORZĄDU W POLSCE
}

Dyskusja na temat roli samorządu w systemie ustrojowym Polski w sposób jednoznaczny powiązana jest z naszym dążeniem do wolności, do demokracji i państwa, w którym to obywatele są prawdziwym suwerenem. W owo dążenie, wyrażone tak dobitnie w czerwcowych wyborach 1989 r., od samego początku wpisany był postulat samorządności. Na skalę państwa i systemu było to wypełnienie idei wyrażonej w nazwie Solidarności, która jako związek zawodowy miała być niezależna i samorządna. Było to też urzeczywistnienie postulatu „Samorządnej Rzeczpospolitej” - jednego z najważniejszych projektów ideowych ruchu Solidarności z I Krajowego Zjazdu Związku, któremu miałem zaszczyt przewodniczyć w $1981 \mathrm{r}$.

Wybrany 4 czerwca 1989 r. parlament - już po kilku miesiącach, bo w marcu roku następnego - uchwalił ustawę przywracająca instytucje samorządu terytorialnego na poziomie gminy. Tak oto 25 lat temu otwarta została droga do przemian ustrojowych budujących Polskę rozumianą jako wspólnota polityczna wszystkich obywateli - rzeczywista Res Publica.

Towarzyszyło nam wtedy głębokie przekonanie, że warunkiem kształtowania demokracji jest odzyskanie państwa dla obywateli, uwolnienie energii społecznej i potencjału indywidualnej twórczości. Bo demokracja to przecież nie tylko możliwość demokratycznego wyboru władzy politycznej. Demokracja to również możliwość współodpowiedzialności obywateli za sprawy publiczne.

Dlatego właśnie pierwszy demokratyczny rząd premiera Tadeusza Mazowieckiego zapoczątkował proces odzyskiwania państwa i oddawania go obywatelom od punktu najważniejszego. Rozpoczął od odbudowania samorządu terytorialnego na poziomie gminy oraz odtworzenia podstawy intelektualnej dla nowej konstytucji obywatelskiego państwa. Było to możliwe w szczególności dlatego, że wizja tej reformy powstawała od dawna w głowach wybitnych osób. Ten projekt reformy samorządowej stanowił oryginalny przykład działania polskiej inteligencji, angażującej się i biorącej odpowiedzialność za dobro wspólnoty.

Reforma samorządowa okazała się też jedną z najskuteczniejszych metod dekomunizacji naszego życia publicznego. Pokazały to pierwsze wybory samorządowe w 1990 r. oraz rola, jaką w ich skutecznym przeprowadzeniu odegrały komitety obywatelskie Solidarności. To w istocie ci sami ludzie - współtwórcy i uczestnicy ruchu obywatelskiego Solidarności - przeprowadzili dzieło odnowienia ustroju samorządowego w Polsce. 
„Szliśmy po władzę po to, aby oddać ją ludziom!” Tym hasłem w $1997 \mathrm{r}$. rząd, którym miałem zaszczyt kierować przez następne cztery lata, wyrażał cel i sens politycznych przemian ustrojowych i społecznych. Nazwaliśmy je Programem Czterech Reform. Poprzez ten program mieliśmy wolę doprowadzić do istotnych przekształceń ustroju życia publicznego. $Z$ jednej strony zamierzaliśmy stworzyć dogodne warunki do rozwoju w Polsce przestrzeni obywatelskiej, z drugiej - zdynamizować procesy rozwoju cywilizacyjnego $\mathrm{w}$ sensie gospodarczym, politycznym i kulturowym.

Towarzyszyło nam przeświadczenie, że przyspieszenie modernizacji i rozwoju zależeć będzie od aktywnego zaangażowania struktur samorządowych. Tym samym wzmacnianie samorządności stawało się dla nas coraz mocniej uświadomionym i coraz pilniejszym zadaniem cywilizacyjnym. Zadanie to podyktowane było w równym stopniu potrzebą właściwego zagospodarowania naszej właśnie odzyskanej niepodległości, jak i potrzebą skutecznego wykorzystania perspektywy naszego członkostwa w Unii Europejskiej. Wtedy już - realnie bliskiej.

Stąd reforma administracyjna, która podjął mój rząd w 1999 r., wprowadzała powiaty jako stopień samorządu pozwalajacy wraz z gminami skutecznie przejąc odpowiedzialność za sprawy bezpośrednio dotyczące lokalnych społeczności i mieszkańców. Jednocześnie utworzenie samorządu na poziomie silnych województw - regionów - decentralizowało odpowiedzialność za rozwój gospodarczy regionów, ich konkurencyjność i strategię modernizacji.

Dzisiaj, po ponad dziesięciu latach naszego członkostwa w strukturach Unii Europejskiej, warto zwrócić uwagę na to, jak podjęte przez nas reformy ustrojowe wpłynęły na nasze funkcjonowanie w systemie integracji europejskiej. Potwierdziło się przede wszystkim jedno z naszych założeń, że decentralizacja i funkcjonalne zróżnicowanie struktur państwa pozwolą Polsce lepiej i efektywniej wykorzystywać oddane do jej dyspozycji środki unijne.

Dzięki trójstopniowej strukturze samorządu stworzyliśmy solidny fundament do pełniejszego zaspokojenia aspiracji naszych obywateli, wspólnot lokalnych oraz regionów co do modernizacji i rozwoju. Dziś to realnie podmioty samorządowe - te najbliższe mieszkańcom, najlepiej znające i rozumiejące potrzeby obywateli - sa odpowiedzialne za budowanie programów rozwoju regionalnego i zarządzanie dostępnymi na ten cel środkami. Samorządy stały się więc rzeczywistymi ośrodkami formowania i realizacji impulsów rozwojowych.

W ten kontekst wpisuje się także kluczowe wyzwanie, jakim jest stymulowanie przedsiębiorczości, przygotowanie odpowiednich warunków do tworzenia innowacji i aktywizacja obywateli - zarówno w sferze gospodarczej, jak i inicjatyw społecznych. Rola samorządów w kształtowaniu polityki rozwojowej państwa nie ogranicza się przecież jedynie do dzielenia dostępnych środków. Ważniejsze są zdolność do efektywnego ich mnożenia, wspieranie partnerstwa, także publiczno-prywatnego, tworzenie silnych powiazań pomiędzy przedsiębiorstwami, ośrodkami naukowymi i administracją lokalna, ułatwianie współpracy między poszczególnymi samorządami oraz wspieranie inicjatyw obywatelskich służacych dobru wspólnemu oraz działań innowacyjnych. Od tego przecież zależeć będzie trwałość rozwoju naszych wspólnot i naszego 
państwa, a to jest przecież dziś kluczowy wymiar odpowiedzialności za sprawy publiczne, która tak głęboko wpisana jest w ideę samorządności.

Reforma samorządowa zapoczątkowana ideami wypracowanymi jeszcze w ramach ruchu Solidarności w latach osiemdziesiątych i wprowadzana w niepodległej już Polsce była fundamentem przebudowy państwa i demokratyzacji relacji obywatel-państwo. Ale miała ona także, a może przede wszystkim wymiar głęboko ideowy, o którym łatwo zapomnieć, koncentrując się na bieżących i najpilniejszych wyzwaniach.

W moim przekonaniu, w samorządności, ale także w kulturze politycznej i administracyjnej, wyraża się nasza możliwość budowania wolności. Wolności, której sens czujemy najlepiej wtedy, gdy możemy za nią współodpowiadać. W okresie niepodległości oznacza to możliwość osobistego zaangażowania w rozwiązywanie - na zasadach pro publico bono - spraw publicznych. Spraw dotyczących życia naszej rodziny, wspólnoty lokalnej i regionu, czy wreszcie całego kraju.

Dziś, w kontekście naszej współodpowiedzialności za Unię Europejska, takie rozumienie samorządności powinno też inspirować nas do poszukiwania kierunków rozwoju oraz kształtowania standardów działania publicznego w skali Europy. Tak jak w Polsce 25 lat temu na samorządności fundowaliśmy wspólnotę polityczną wszystkich obywateli, tak dziś w samorządności powinniśmy upatrywać szans na realną wspólnotę polityczną wszystkich obywateli Europy.

prof. dr hab. Jerzy Buzek

Przewodniczacy Komisji Przemystu, Badań i Energii Parlamentu Europejskiego,

Przewodniczacy Parlamentu Europejskiego w latach 2009-2012,

Prezes Rady Ministrów RP w latach 1997-2001

\section{A SELF GOVERNING REPUBLIC \\ -25 YEARS OF SELF-GOVERNMENT IN POLAND}

The discussion of the role of self-government in Poland's political structure has been closely linked to the Polish people's aspirations and desire for freedom, democracy and a state in which sovereignty is indeed in the hands of its people. These aspirations, so strongly expressed during the general election of June 1989, have since the very beginning included demands for selfgovernment. What it meant for the state and its political system, was the implementation of the idea embodied in the name Solidarity which, as a trade union, was also to be independent and self-governing. It was also the realisation of the demand for a 'Samorzadna Rzeczpospolita' (a Self-governing Republic), one of the fundamental principles of the Solidarity movement put forward at its First National Congress, which I had the honour of chairing in 1981.

In March 1990, only a few months after its election on 4 June 1989, the Polish parliament adopted a law that restored the institution of local self-government at the level of communes and municipalities (gmina). Thus, 25 years ago, the road to political transformation in Poland was opened, allowing the building of a Polish state understood as the political community of all its citizens - a real Res Publica.

The predominating belief which accompanied us in this process was that the indispensable prerequisite to shaping democracy was to give back the state to its citizens, thus releasing dormant social energy and the entrepreneurial spirit of the people. After all democracy means not only the possibility of the democratically electing the political representatives (the authorities) but equally the chance for citizens to feel involved and take the responsibility for public affairs. 
Therefore the first democratic government, headed by Tadeusz Mazowiecki, began the process of restoring the state to its citizens from the most important starting point. It started with the rebuilding of communal and municipal self-governing structures and the recreating of the intellectual foundations for the formation of the new constitution of a citizens-centred state.

This was possible mainly because a vision of reform had already been conceived and had been long developing in the minds of a number of distinguished persons. This project of self-government reform constituted an original example of engagement of Polish intellectuals in state affairs and their taking responsibility for the common good.

The reform also turned out to be one of the most effective methods of de-communisation of Polish public life. This could be best seen in the results of the first election to self-governing structures in 1990, and the role which the Solidarity citizens' committees played in it. It was indeed the same people, the co-founders and members of the Solidarity movement, who have successfully carried out the restoration of self-government in Poland.

'We marched for power to return it to the people' was the motto of the Polish government in 1997, a government which I had the honour of heading for the subsequent four years, and which articulated the goals and the sense of political and social transformation of those times. We called it a Four Reform Programme, and its objective was a fundamental transformation of public life in Poland. On the one hand we intended to create favourable conditions for the development of the public civic space, while on the other we strove to activate and make more dynamic the processes of economic, political and cultural development in the country.

We believed that acceleration of this development and modernisation was contingent upon active participation of self-government structures. Hence the creation of strong self-government had gradually become our conscious choice and an urgent 'civilising task.' This task was grounded equally in the need to manage properly our recently regained independence, and in the need to make efficient use of the pre-accession period preceding Poland's membership of the European Union, which was then imminent.

Thus the administrative reform undertaken by my government in 1999 introduced districts (powiat) as self-governing level of administration, allowing it, in conjunction with communes and municipalities (gmina), to take effective control of matters directly affecting local communities and their citizens. The self-governing structures formed at the level of strong voivodships, or regions, allowed at the same time to decentralise responsibility for regional economic development, competitiveness and modernisation strategies.

Today, after over 10 years of EU membership, it is worth reflecting on the impact the political reforms which we carried through then have had on Poland's functioning in the system of European integration. We were proven right in our conviction that decentralisation and differentiation of various state functions would allow for a better and more effective use and management of EU funds.

The three-tier self-government structure created solid foundations helping to satisfy better the aspirations of citizens, local communities and regions with regard to their modernisation and development. Today it is those local self-governing units, those closest to citizens, those most familiar with and with the best understanding of their needs, which are responsible for the drafting of regional development projects and the management of funds available for those projects. Self-government structures have become the real centres for formulating and implementing development strategies.

This is the context in which the key challenge facing self-government is set, namely the fostering of entrepreneurship, ensuring proper conditions for innovation and mobilising citizens to engage in economic and social initiatives. The role of self-government in shaping of the state's development policy is not limited to dividing available means and resources. Much more important is its ability to effectively multiply the available means, to support partnership ventures, including public-private projects, to form strong business to business relationships as well as partner relations between research centres and local administrative bodies, or promote and support innovations and civic initiatives serving the common good. After all, all these are key factors for the long-term stability and development of our communities and our country, which is today the key measure of the responsibility for public matters, so deeply rooted in the idea of self-government.

The self-government reform originated from the ideas developed in the 1980 s of the twentieth century as part of the Solidarity movement, but was implemented in an already independent 
Poland, when laying the foundations for a transformation of the state and the democratisation of the citizen-state relationship. It also had, however, and maybe predominantly, a deep idealistic dimension, so easy to forget when we focus on the current and most urgent challenges of the present.

In my opinion, it is in self-governance, as well as in the political and administrative culture, that opportunities for building our freedom lie: freedom, the sense of which we feel best if given a chance to share in the responsibility for it. In times of independence this means the possibility of personal engagement public issues based on the pro publico bono principle: issues pertaining to our family life, our local community, or the whole country.

Today, in the context of our shared responsibility for the European Union, such an understanding of self-governance should also inspire us to seek new directions of development, and to participate in the shaping of Europe-wide standards of public life. In the same way as 25 years ago in Poland we founded a political community on the basis of self-governance, we should today look at self-governance as a chance to create a true political community of all European citizens. 
